\title{
風洞による鉄塔模型の振動実験
}

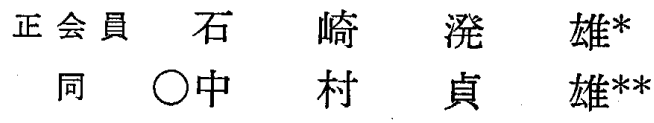

はしがき 風によって生じる鉄塔の振動については、 今日な和不明な点が多い。風化乱れがあるとき、すなわ ち風速が変動するときには、鉄塔飞振動の生じることる 容易汇考学られるが、風速一定の場合にも振動を生じる るのであるかどうか、生じるとすれば、どのような場合 飞生じるかを明らかとする目的で、風洞内の模型実験を 行ってみた。問題は複雑で、今回の実験結果のみでは、 とうてい結論を得られないが、実験の概要を以下に報告 する。

1. 模型 実験に用いた 模型は、A,B,C の三種で、 各々は第 1 図々示す構面を もつ四角柱である。部材は 第 1 図の下示す断面在す つアングル，材料はポりエ ステルで、充実率はそれぞ 机模型 $\mathrm{A}$ は 0.33 , 模型 $\mathrm{B}$ は 0.27 , 模型 $\mathrm{C} 0.21$ で ある。

2. 装置 模型の下端を 支持台に固定し、模型の 4 本の柱脚下部にストレイン ゲージをはり、その歪を動 歪計により測定し、電磁オ

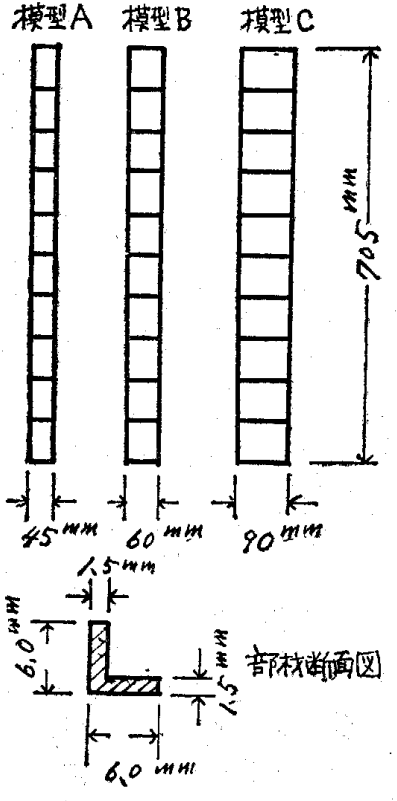

第 1 図 模 型
シログラフそ記録した。4本の柱脚の歪と模型塔体頂部 の変位との関係は、あらかじめ実測して求めた。模型の 頂部に錘をつけ、その重さを変えることによって、模型 の固有振動周期を変えることができる。

3. 実験経過 まず予備実験で次の上うな結果を得 た。模型の頂部々錘をつけない場合は、模型ははが固有 周期で振動しているが、風速 $18,19,20 \mathrm{~m} / \mathrm{sec}$ のとき、 固有周期の他飞、約 $0.09 \mathrm{sec}$ の周期の振動も若干生じ ている。銼を増して、模型の固有周期を約 $0.09 \mathrm{sec}$ 亿 すると、風速 $20 \mathrm{~m} / \mathrm{sec}$ 附近で、振幅はいちじるしく大 きくなる。さらと鏵を増して、固有周期を $0.09 \mathrm{sec}$ よ りも大きくしても、この程度の風速で、振幅は增大しな
合について、風 速 $4 \sim 30 \mathrm{~m} / \mathrm{sec}$ 位の範囲の実験 を行った。

\section{4. 実験結果}

結果の一部を 第2 図に示す。 いずれも模型 の固有周期が、 $0.09 \sec の$ とき 風速 $18,19,20$ $\mathrm{m} / \mathrm{sec}$ で、最も 振巾は大きくな る。錘がなくて 固有周期と 0.09 $\mathrm{sec}$ 周期との差 が大きいとき は、振幅は風速 と共笚調増加 する傾向である が、風速 $19 \mathrm{~m} /$ sec位で柱、0.09 $\sec$ の周期の振 動を伴うため
第 1 表 実験の状 態

\begin{tabular}{|c|c|c|c|c|c|}
\hline 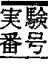 & 模型 & $\left(\begin{array}{l}\text { 鏵 } \\
(\mathbf{g})\end{array}\right.$ & $\begin{array}{c}\text { 固有周期 } \\
\text { (sec) }\end{array}$ & 減衰比 & \begin{tabular}{|l} 
棈面と風向 \\
との傾き角
\end{tabular} \\
\hline 1 & A & 0 & 0.040 & 7.21 & $0^{\circ}$ \\
\hline 2 & A & 55 & 0.073 & 1.32 & $0^{\circ}$ \\
\hline 3 & A & 91 & 0.090 & 1.27 & $0^{\circ}$ \\
\hline 4 & A & 91 & 0.090 & 1.27 & $45^{\circ}$ \\
\hline 5 & B & 0 & 0.040 & 1.36 & $0^{\circ}$ \\
\hline 6 & B & 115 & 0.090 & 1.33 & $0^{\circ}$ \\
\hline 7 & B & 115 & 0.090 & 1.33 & $45^{\circ}$ \\
\hline 8 & B & 115 & 0.090 & 1.33 & $20^{\circ}$ \\
\hline 9 & B & 200 & 0.118 & 1.22 & $0^{\circ}$ \\
\hline 10 & C & 0 & 0.055 & 1.28 & $0^{\circ}$ \\
\hline 11 & C & 68 & 0.090 & 1.34 & $0^{\circ}$ \\
\hline 12 & C & 135 & 0.116 & 1.34 & $0^{\circ}$ \\
\hline
\end{tabular}

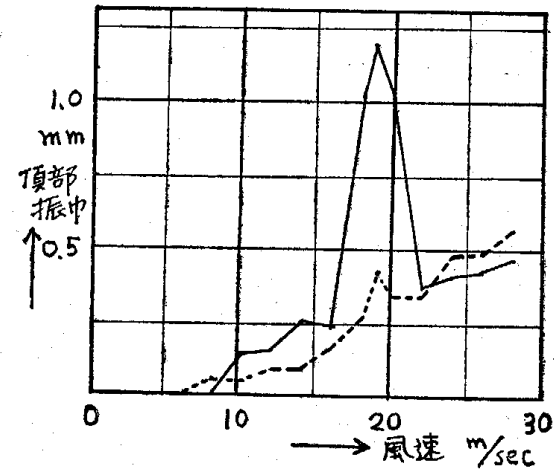

第 2 图模型 $B$ 実線注固有周期 $0.040 \mathrm{sec}$ （第 1 表の実験番号 5 ) 点線注固有周期 $0.090 \mathrm{sec}$ （第 1 表の実験番号 6 )

に、や〉振幅は大きくなる。

いずれの場合も頂部の振動方向は、ほ 振動周期は、添よ゙固有周期である。

風速 $19 \mathrm{~m} / \mathrm{sec}$, 固有周期 $0.09 \mathrm{sec}$ の模型の振幅は、 いちじるしく大きいが、これの振動しているとき、模型 の風下より、棒を模型に約 $1 \mathrm{~m}$ 位まで近ずければ、模型 の振動は、明らかに小さくなる。このことから、後流が 模型の掁動に影響しているのではないかと考えられる。

次飞模型Aについて、固有周期を第 1 表の場合上りる

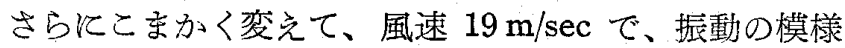
が、どのように変るか実験してみた。その結果を第 2 表 と示す。

いことがわかつた。以上の

予備実験泟とづいて、第

1 表に示すような種々の場

* 京都大学防災研究所教授

工博

** 同研究生
第 2 表 風速 $19 \mathrm{~m} / \mathrm{sec}$ で模型 $\mathrm{A} の$ 固有周期を変えたときの振巾の変化

\begin{tabular}{|c|c|c|c|c|c|c|c|c|c|}
\hline 錘 $\quad(\mathrm{g})$ & 35 & 55 & 69. & 81 & 91 & 101 & 111 & 123 & 143 \\
\hline 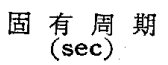 & 0.062 & 0.073 & 0.078 & 0.082 & 0.088 & 0.092 & 0.096 & 0.100 & 0.107 \\
\hline 最大振幅の比 & 0.44 & 0.48 & 0.54 & 0.64 & 0.79 & 1.00 & 0.65 & 0.46 & 0.41 \\
\hline 振ウの特長 & 不規則 & $\begin{array}{l}\text { ビートのよ } \\
5 な \text { 状態 }\end{array}$ & $\mid \begin{array}{l}\text { ビートのよ } \\
\text { 万な状態 }\end{array}$ & $\left|\begin{array}{l}\text { ピートのよ } \\
5 \text { な状態 }\end{array}\right|$ & ほよ゙一様 & ほメ゙一様 & $\mid \begin{array}{l}\text { ビートのよ } \\
5 \text { な状態 }\end{array}$ & $\left|\begin{array}{l}\text { ビートのよ } \\
5 \text { な状態 }\end{array}\right|$ & $\begin{array}{l}\text { ビートのよ } \\
5 \text { な状態. }\end{array}$ \\
\hline
\end{tabular}

